\author{
Michat DaHL \\ Uniwersytet Mikołaja Kopernika w Toruniu \\ ORCID ID: https://orcid.org/0000-0003-2803-2648

\section{Maria LEWANDOWSKA} \\ Uniwersytet Mikołaja Kopernika w Toruniu \\ ORCID ID: https://orcid.org/ 0000-0002-0448-7181
}

\title{
Sprawozdanie z IV Zimowej Szkoły Metodologicznej, Toruń, 21-22 lutego 2019 roku
} Report from the IV Winter Methodological Workshops, Toruń, February 21-22, 2019 Отчет о IV методической школе, Торунь, 21-22 февраля 2019 года

W dniach 21-22 lutego 2019 roku na Wydziale Politologii i Studiów miała miejsce IV Zimowa Szkoła Metodologiczna. Organizatorami wydarzenia, podobnie jak w przypadku poprzednich edycji, była Katedra Teorii Polityki WPiSM UMK oraz Sekcja Metod, Technik i Narzędzi Badawczych Polskiego Towarzystwa Nauk Politycznych. Choć organizowana jest dopiero po raz czwarty, dzięki wysokiemu poziomowi merytorycznemu oraz sprawnej organizacji kolejnych edycji, Zimowa Szkoła Metodologiczna zaliczana jest do najważniejszych konferencji metodologicznych w kraju. Inicjatywa zapoczątkowana przez prof. dr. hab. Romana Bäckera, kierownika Katedry Teorii Polityki WPiSM UMK, szybko stała się docenianą i cieszącą się rosnącą 
popularnością platformą komunikacji między młodymi badaczami - przedstawicielami nauk społecznych - a uznanymi autorytetami w dziedzinie metodologii i tworzenia projektów badawczych. Konferencja adresowana jest nie tylko do naukowców prowadzących badania z zakresu politologii, ale również przedstawicieli m.in. stosunków międzynarodowych, nauk prawnych, nauk o bezpieczeństwie i nauk o mediach, chcących poddać ocenie założenia swojego wniosku grantowego, artykułu naukowego lub pracy licencjackiej, magisterskiej, dysertacji doktorskiej lub rozprawy habilitacyjnej (Dahl, 2018). W tym roku organizatorzy w sposób szczególny zachęcali do udziału w konferencji wszystkie osoby, które planują rozpoczęcie nauki w szkołach doktorskich, ze względu na bardzo duże znaczenie metodologii w tworzeniu projektów badawczych.

Warunkiem udziału w Zimowej Szkole Metodologicznej - poza przygotowaniem założeń prezentowanego projektu - jest gotowość do skonfrontowania swoich pomysłów z opiniami ekspertów i uczestników konferencji, umiejętność prowadzenia dialogu i przyjmowania konstruktywnej krytyki, która nie ma przecież na celu zniechęcenia badacza, ale poszerzenie jego horyzontów badawczych i zmuszenie do refleksji, skutkującej podniesieniem wartości poddanych analizie projektów.

Do udziału w tegorocznej edycji konferencji organizatorzy zakwalifikowali dwudziestu prelegentów, reprezentujących: Uniwersytet im. Adama Mickiewicza, Uniwersytet Jagielloński, Uniwersytet Marii Curie-Skłodowskiej, Uniwersytet Mikołaja Kopernika w Toruniu, Uniwersytet Wrocławski, Uniwersytet Rzeszowski, Uniwersytet Szczeciński, Polską Akademię Nauk oraz SWPS Uniwersytet Humanistycznospołeczny. Zgłoszone projekty badawcze oceniali przewodniczący Komitetu Naukowego konferencji: prof. dr hab. Roman Bäcker (UMK) i dr Krzysztof Kasianiuk (Collegium Civitas), a także dr hab. Kazimierz Dziubka, prof. UWr, dr hab. Monika Klimowicz (UWr), dr Joanna Rak (UAM) i dr Wiktor Szewczak (UMK).

Pierwszy dzień konferencyjnych zmagań rozpoczął się uroczystym otwarciem obrad i powitaniem zaproszonych gości, dokonanym przez prof. dr. hab. Romana Bäckera. Wykład ekspercki, poświęcony procedurze składania wniosków o finansowanie badań naukowych do Narodowego Centrum Nauki, wygłosiła reprezentująca NCN dr Aneta Pazik, koordynator dyscyplin w dziale nauk humanistycznych, społecznych i o sztuce. Omówiła pokrótce 
zasady wszystkich konkursów organizowanych przez NCN, dzięki czemu uczestnicy mogli dowiedzieć się, w którym z nich mogą spróbować swoich sił. Ponadto zwróciła uwagę na błędy najczęściej popełniane przy składaniu wniosków. Bezpośrednio po wykładzie eksperckim rozpoczęły się obrady panelowe. Osiem wystąpień zostało rozdzielonych na trzy panele, zbliżone do siebie strukturą. Po ok. 20-min. wystąpieniu prelegenta swoje pytania odnoszące się do treści projektów badawczych i uwagi merytoryczne mogli formułować recenzujący projekty eksperci oraz wszyscy uczestnicy konferencji.

Panel pierwszy zainaugurowało wystąpienie dr hab. Moniki Klimowicz i dr hab. Małgorzaty Michalewskiej-Pawlak, reprezentujących Uniwersytet Wrocławski (Implementacja inwestycji społecznych $w$ państwach członkowskich Unii Europejskiej). Następnie głos zabrał dr Rafał Kamprowski z Uniwersytetu im. Adama Mickiewicza (Bezpieczeństwo zdrowotne seniorów w europejskiej sieci zdrowych miast), po nim zaś - dr Wojciech Łysek z Polskiej Akademii Nauk (Aktualność rozważań Juliusza Mieroszewskiego w zakresie polskiej polityki wschodniej po 2015 roku).

W panelu drugim jako pierwsza wystąpiła mgr Marta Cimke z Uniwersytetu Jagiellońskiego (Wpływ dewolucji na partie polityczne i system partyjny w Zjednoczonym Królestwie Wielkiej Brytanii i Irlandii Pótnocnej). Projekt zatytułowany Istota instytucji nadzoru nad działalnością samorządu terytorialnego zaprezentował następnie mgr Karol Piękoś z Uniwersytetu Rzeszowskiego. Kolejnym prelegentem był reprezentant Uniwersytetu Marii Curie-Skłodowskiej - mgr Grzegorz Mazur, który przedstawił projekt pt. Jak pracuje umysł wybitnego polityka - Jarosław Kaczyński - studium przypadku.

W panelu III założenia swoich projektów badawczych zaprezentowali mgr Damian Wicherek (UR) i mgr Ewelina Nowakowska (SWPS). Wystąpienia dotyczyły - odpowiednio - Kancelarii Prezydenta RP jako organu pomocniczego oraz autoidentyfikacji ideowej młodej prawicy i młodej lewicy w Polsce po 2015 roku. Zwieńczeniem pierwszego dnia obrad był wykład dotyczący struktury tekstu naukowego, zaprezentowany przez prof. dr. hab. Romana Bäckera i dr Joannę Rak. Eksperci przedstawili schemat oraz zasady procesu recenzyjnego, z jakim będą miały do czynienia osoby chcące opublikować tekst w czasopiśmie ze współczynnikiem impact factor (wskaźnik cytowań). 
Drugiego dnia konferencji uczestnicy obradowali w dwóch równoległych panelach. W panelu 1A zaprezentowali się: mgr Bartosz Płotka (UMK; Dynamika polskiej myśli biopolitycznej. Analiza projektów ustaw dotyczących kwestii biopolitycznych w latach 1989-2015 z wykorzystaniem zbiorów rozmytych) oraz mgr Bartosz Mazurkiewicz (US; Polityczne i pozapolityczne czynniki wielokadencyjności burmistrzów - w poszukiwaniu prawidłowości); w panelu 1B natomiast - mgr Piotr Majewski (UMK; „Erozja potęgi supermocarstw w pozimnowojennym systemie międzynarodowym") i lic. Mikołaj Lisewski (UMK; Typologie nacjonalizmu z perspektywy teorii polityki. Ujęcie metodologiczne).

Przedstawiciele Uniwersytetu Mikołaja Kopernika: panowie Jakub Zemła i Jan Majewski, a także pan Marcin Dorochowicz zaprezentowali swoje projekty badawcze w panelu 2A (odpowiednio: Funkcjonowanie polskiego systemu ochrony zdrowia na osi płatnik-świadczeniodawca. Analiza prawno-socjologiczna i Prokuratorska kontrola aktów stanowienia prawa). Pierwszym prelegentem panelu 2B był mgr Dominik Boratyn z Uniwersytetu Rzeszowskiego, który zaprezentował projekt zatytułowany Kreowanie wizerunku gminy na przykładzie miast na prawach powiatu województwa podkarpackiego. Kolejnymi panelistami byli: mgr Maria Lewandowska (UMK; Relacje ukrainsko-rosyjskie według tweedów Petra Poroszenki i Dmitrija Miedwiediewa), mgr Tomasz Sińczak (UMK; Wojna domowa w Syrii. Powrót Rosji do koncertu mocarstw?) oraz mgr Kamila Rezmer (UMK; „Agenda kościelna a polityczna w Polsce w latach 2015-2019”).

O godz. $12^{15}$ wszyscy uczestnicy spotkali się na wykładzie dr. hab. Kazimierza Dziubki, prof. UWr, poświęconym zagadnieniu budowania teorii, po którym nastąpiło oficjalne zakończenie konferencji.

Organizatorzy już teraz zapraszają do udziału w kolejnej edycji Zimowej Szkoły Metodologicznej, uznanej przez uczestników tegorocznego spotkania za inicjatywę wartościową i potrzebną nie tylko ze względu na dyskusje prowadzone podczas poszczególnych paneli. Równie istotne okazują się rozmowy toczone w kuluarach, umożliwiające rozwinięcie interesujących wątków, które ze względu na ograniczony czas przeznaczony na poszczególne wystąpienia, musiały zostać przedwcześnie zakończone w części oficjalnej. Zimowa Szkoła Metodologiczna to okazja do wymiany uwag, spostrzeżeń 
i praktyk stosowanych przez badaczy z całej Polski, przede wszystkim na poziomie metodologicznym.

MGR MICHAŁ DAHL

Wydział Politologii i Studiów Międzynarodowych

Uniwersytet Mikołaja Kopernika w Toruniu

ul. Stefana Batorego 39L, 87-100 Toruń, Poland

dahl.michal@gmail.com

MGR MARIA LEWANDOWSKA

Wydział Politologii i Studiów Międzynarodowych

Uniwersytet Mikołaja Kopernika w Toruniu

ul. Stefana Batorego 39L, 87-100 Toruń, Poland

maria-lewandowska@o2.pl

\section{Bibliografia}

Dahl, M. (2018). Sprawozdanie z III Zimowej Szkoły Metodologicznej, Toruń, 17 marca 2018 roku. Nowa Polityka Wschodnia, 16, 141-143. 